\title{
Research on Strength Properties of Concrete by Partial Replacement of Cement with Rice Husk Ash
}

\author{
Sarmilee Patnaik, S. Ashish, G. Devi Vara Prasad, G. Srikanth
}

\begin{abstract}
A vibrant part of the cement will bond as a cover that ties separate segments different, technology of substances this coupling has turn out to be concrete costly more high priced and the creation of add-contamination ecology with the use of $\mathrm{CO} 2$ is the driver essential of Earth-wide impetus temperature so that the measures adopted to normal sturdy asset or environmental waste used as set up material.RHA strengthening is bye-yield rice industry, deeply responsive pozzolana added by using copying the rice husk at controlled temperatures. Because the fee of contamination ecology and mind increasing preservation factor became made the use of rice husk.
\end{abstract}

Catchphrases: Cement stable, skin debris Rice, Fly debris.

\section{INTRODUCTION}

The usage of mechanical and biogenic spend on strengthening concrete fabric present installation as a monetary energy and assets. Most of the cloth pozzolan and set up treasured generally utilized the consequences of cutting-edge soil sand effect of heating slag, metakaolin, rice husks particles (RHA), silica coal, ground sand slag heating and fly ash, a waste glass powder as opposed to concrete slag effect heater, flying debris and particles of wooden and so on materials. Its use not most effective improve the concrete also reduces the burden skilled. These effects solid all the way down to earth at danger there to pollute and for that reason enlarge the difficulty of switch and cost. India is the huge variety of ongoing Chinese rice husks are made every year from the chaff while consumed beneath managed temperatures produce pores and skin that is higly pozzolana obtained had 90-ninety five\% silica may be used for the substitution of bonds upto a sure stage. Rice skin debris includes Cellulose

(C5H10O5), Lignin (C7H10O3), hemicellulose, SiO2, Holocellulose.The silicate is a phase which offers for a pozzolanic reactivity with recognize to rice husk debris.

As a ways INVESTIGATION OF PRESENT

- To decide the bodily houses of RHA

- To decide the expected slump new cement supplantings exclusive degrees with the RHA.

- To decide the best degree of RHA as a whole alternative

Revised Manuscript Received on September 14, 2019.

Sarmilee Patnaik, Assistant Professor, Department of Civil Engineering, Siddhartha Institute of Technology and Sciences, Hyderabad, Telangana, India. (E-mail: Srp558.53@gmail.com)

S. Ashish, Assistant Professor, Department of Civil Engineering, Siddhartha Institute of Technology and Sciences, Hyderabad, Telangana, India.

G. Devi Vara Prasad, Assistant Professor, Department of Civil Engineering, Siddhartha Institute of Technology and Sciences, Hyderabad, Telangana, India.

G. Srikanth, Assistant Professor, Department of Civil Engineering, Siddhartha Institute of Technology and Sciences, Hyderabad, Telanagana, India. essential difficulty to acquire the natural putting of spare

of the bond.

- To decide the best press, break up elasticity and bending best with distinct tiers of substitution of RHA.

\section{EXPERIMENTAL PROGRAM \& RESULTS}

the check application consists of tests of cement standard assessment and in addition with the aid of replacing the bonds in part with rice husk debris.

\section{Rice Husk ash}

debris rice husks utilized in that is furnished by way of the Company is placed at Medchal A.Brahmni Hyderabad place, Telengana. Rice husk particles within the dark gray shading with explicit gravity of one.Seventy seven and a fineness of $8.75 \%$.

\section{Tests on Concrete}

A combination of M25 and M35 structured in accordance with the regulations of IS rely upon fundamental investigations lead in constituent substances 10262-1982. The materials used and their properties collectively as far because the aggregate for a final mix become brought in Table-1.

\section{Concrete function}

RHA alternatives in a strong combination will make bigger water call for contrasts with a mixture of manage, so the water is covered to preserve the usability and to get the suitable hunch as concrete incentives manipulate.

Table-1 Properties of materials used and mix proportion for M25 and M35 mix

\begin{tabular}{|c|c|c|c|c|}
\hline \multirow[t]{2}{*}{ Materials } & \multicolumn{2}{|c|}{ Quantity $\mathrm{Kg} / \mathrm{m}^{3}$} & \multirow[t]{2}{*}{ Test conducted } & \multirow[t]{2}{*}{ Result } \\
\hline & $\mathrm{M}_{25}$ & M35 & & \\
\hline \multirow[t]{4}{*}{ Cement } & \multirow[t]{4}{*}{383.2} & \multirow[t]{4}{*}{410} & $\begin{array}{c}\text { Standard } \\
\text { consistency }\end{array}$ & $35 \%$ \\
\hline & & & Initial setting time & $125 \mathrm{~min}$ \\
\hline & & & Final setting time & $420 \mathrm{~min}$ \\
\hline & & & $\begin{array}{c}\text { compressive } \\
\text { strength }\end{array}$ & $42.7 \mathrm{~N} / \mathrm{mm}^{2}$ \\
\hline \multirow{2}{*}{$\begin{array}{c}\text { Fine } \\
\text { aggregate }\end{array}$} & \multirow[t]{2}{*}{560} & \multirow[t]{2}{*}{595} & Specific gravity & 2.67 \\
\hline & & & $\begin{array}{l}\text { Grain size } \\
\text { distribution }\end{array}$ & Zone V \\
\hline $\begin{array}{c}\text { Coarse } \\
\text { aggregate }\end{array}$ & 1295 & 1255 & Specific gravity & 2.84 \\
\hline Water & 191.6 & 186 & & \\
\hline
\end{tabular}




\section{RESEARCH ON STRENGTH PROPERTIES OF CONCRETE BY PARTIAL REPLACEMENT OF CEMENT WITH RICE HUSK ASH}

\section{Tests on Hardened Concrete}

Three specimens of every solid with extraordinary chances of cement replacement varies from zero\% to fifteen $\%$ by using RHA hardened concrete.

Tap the Power Cube

To observe the results of substitute percentage (zero\% to $15 \%)$ of the RHA delivered to the concrete and the consequences at 7 and 28 days are shown in Figure-1, 2, three respectively. Strength on the age of 28 days is proximate to the concrete manage for the above-cited values are $10 \%$ RHAand5\% RHA.

Comparison of compressive energy with the M25 and M35 (0\% to $15 \%)$ cement substitute at age 7 days enough proven in figures 1 .

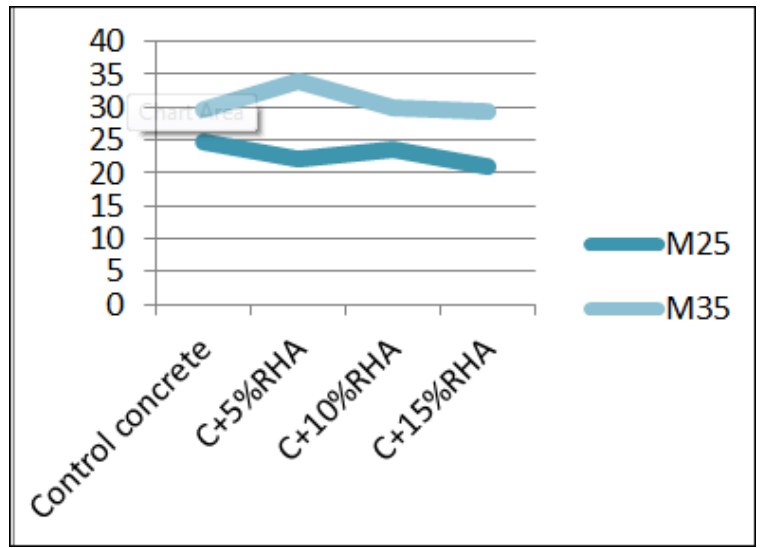

Fig-1 Variation of compressive strength at the age of 7 days

Comparison of compressive strength of $\mathrm{M}_{25}$ and $\mathrm{M}_{35}$ with $(0 \%$ to15\%) replacement of cement at the age of 28 days is shown in fig-2.

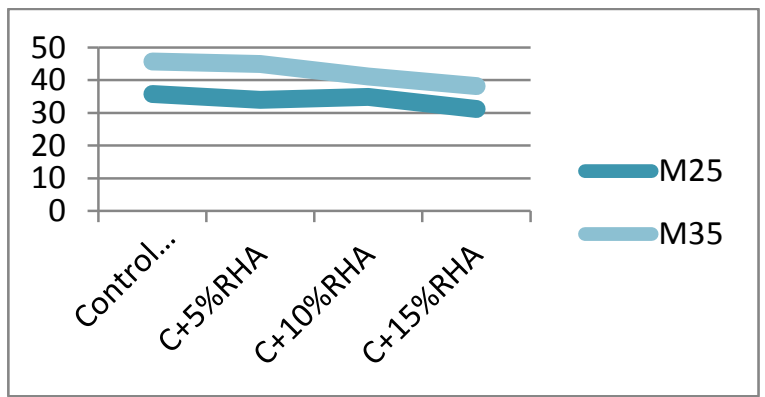

Figure 2 Variation of compressive energy at 28 days

Split tensile electricity

Optimal percentage elevated cement substitute commented in split tensile energy of manage mix of M25 and M35 at 28 days become $10 \%$ RHA.

Comparison of the cut up tensile energy of M25 and M35 with $(0 \%$ to fifteen $\%)$ cement substitute on the age of 28 days are shown in sufficient numbers3.

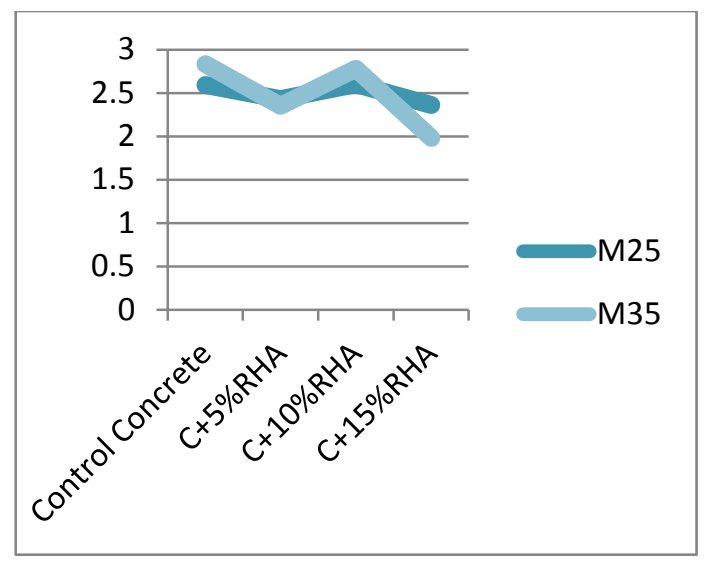

Fig-3 Variation of split tensile strength at the age of 28 days

\section{Flexural Strength}

The increase in electricity supple percent growth mis replacement of $(5 \%-15 \%)$ of the RHA, can be seen in $15 \%$ of RHA alternative to the M25 and M35 extra strength.

Comparison of flexural tensile energy from the M25 and M35 with (0p.Cto15\%) cement replacement at the age of 28 days shown in the figure-four.

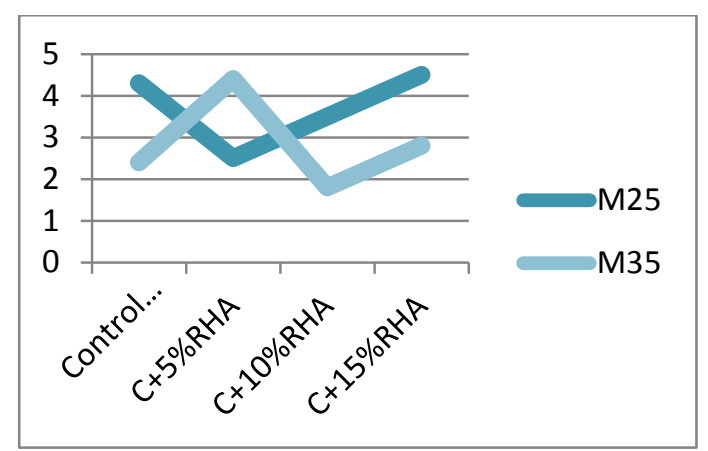

Fig-4 Variation of flexural tensile strength at the age of 28 days

\section{CONCLUSIONS}

1. Incorporation of RHA inside the bond call for additional water into permeable substances contrasted and concrete so the workmanship is kept up with the guide of including water.

2. The compressive quality at 7 and 28 days is ideal as contrasted and oversee concrete at $10 \%$ of RHA to blend M25 school room. Also, M35 control debut mix of five\% RHA of conventional directions on the age of 7 and 28 days separately.

3. Partition the pliable power expanded at an ideal substitution of bond through 10\% RHAfor M25 and M35 grade solid blend of the solid oversee of 28 days for each greatness.

4. Expanding the flexural quality at the choicest option of bond with 15\% RHA M25 and M35 evaluations of solid blend at 28 days. 


\section{REFERENCES}

1. C.Marthong (2012) "Impacts of rice husk debris as a fractional substitute of bond in solid houses." ISSN: 2278-0181.

2. Cordeiro, G.C Filho, Fairbairn (2009) "the utilization of ultrafine husk debris with an inordinate carbon content as pozzolan in extreme by and large execution solid" fabric and shape: forty two-983992.

3. Ettu 1.O, Ajoku C.A, Nwachukwu K.C, Awodiji C.T.G, Eziefula U.G (2013) "are varieties of customary Portland bond vitality composite - rice husk debris with a dispersion of rice husk debris percent." ISSN: 2277 9442.

4. Gahassan Abood Habeeb, Hilmi receptacle Mahmud (2010) "The investigation of the character and utilization of rice husk debris as a bond substitution materials. "Materials Research 2010; 13 (2): 185-one hundred ninety.

5. Hanna, Maoatad, N.K (1984) "utilizing rice husk debris in solid." International Journal of composities bond and light-weight concrete. No $6 \mathrm{Vol}$ Degussa creation compound substances.

6. I.B.Ologunagaba, A.S.Daramola, A.O.Aliu (2015) "the plausibility of the use of rice husk debris as a halfway substitute for concrete. "Worldwide Journal of building and period propensities vol 30, no 5.

7. Kartini (2011) "husk debris pozzolan substances to manageability." International Journal of executed science and innovation vol 1 no 6 .

8. K.Ganesan, K.Rajagopal and K.Thangavelu, "Impact of Partial Replacement Agro Cement with debris squander (rice husk debris and Bagasse Ash) at the quality and strength of the Concrete," Proceedings of the International Conference on Recent Advances in Concrete and Construction Technology, 7 to 9 December 2005 SRMIST, Chennai, India pp.73-85.94 22) LOEittu, JCEzeh, UCAnya, KCN Wachukwu, and KONjoku (2013). "tevnary power concrete mixed bond containing rice husk debris and earth Afikpo debris saws ". Worldwide magazine of science disclosure methods.

9. Mahmud, H.B. Koay, Y.C.N.Hamid and Zain, M.F.M (2004) "utilizing rice husk debris to deliver high power extreme by and large execution concrete. "National University of Malaysia.

10. Pathan Ms.Nazia, "Utilization of Abu Rice Husk in making High Performance Concrete," National Seminar on Technological Innovation inside the Development of Concrete Structures 7 th and eight th Feb.2003, Department of Civil Engineering, KITS, Ramtek, Maharashtra State.

11. Naphol Yiibanpoot and Pitthaya Jamsawang (2014) "Impacts of replacemeant bond by means of rice husk debris on delicate soil adjustment." Kasetsart Journal (nat sci) 48: 323-332.

12. N.R.D.Murthy, P.Rathish Kumar, Seshu D.R and M.V. Seshagiri Rao, "Impact of Rice Husk Abu on Strength and solidness of cement," ICI Journal July-September, 2002, pp.3738.

13. O.A. Adenuga, A.A. Soyingbe and O.E. Ogunsanmi, (2010). "The utilization of rice husk debris as a halfway substitution of bond in concrete". Lagos Journal of Environmental Studies.

14. OBILADE, I.O. (2014). "The utilization of rice husk debris as a halfway substitute of bond in concrete". Worldwide diary of designing and completed sciences. EAAS and ARF.

15. P.Chandan kumar, P.Malleswara Rao (2010), "The advantages of the utilization of rice husk debris in solid" diaries of worldwide toxins control.
16. P.Padma Rao, Kumar A.Pradhan, B.Bhaskar Singh (2014). "The investigate utilizing rice husk debris in concrete" .IJEAR.

17. PV Rambabu, J Gopal verma, GV Ramarao (2015) "Concentrates at the obstruction of rice husk debris for bond substitute most fitting stage in concrete" worldwide magazine of building characteristics 